\title{
The Effect of Massage Therapy Using Frangipani Aromatherapy Oil to Reduce the Childbirth Pain Intensity
}

Ni Gusti Kompiang Sriasih, SST, M.Kes, ${ }^{*}$ M. Choirul Hadi, SKM, M.Kes ${ }^{2}$ Ni Nyoman Suindri, S.Si.T., M.Keb, ${ }^{1}$ Gusti Ayu Surati, M.Kes, ${ }^{1}$ Ni Made Dwi Mahayati, SST., M.Keb ${ }^{1}$

${ }^{1}$ Department of Midwifery, Polytechnic of Denpasar, Denpasar, Bali, Indonesia, ${ }^{2}$ Department of Environmental Health, Health Polytechnic of Denpasar, Denpasar, Bali, Indonesia

Background: Pain during labor is one of the worst pains experienced by women. If the woman cannot adapt to it, it may lead to uncoordinated uterine contractions causing a long-complicated labor with the possibility of death of the mother and baby.

Purpose: The aim of the study is to observe the effect of massage treatment using frangipani aromatherapy oil to reduce the childbirth pain intensity.

Setting: Pembantu Dauh Puri Health Center Denpasar, Bali, Indonesia.

Participants: Pregnant women in labor.

Research Design: A quasi-experimental research design was used with pretreatment and posttreatment groups and a control. The respondents were 70 pregnant women in labor in Pembantu Dauh Puri Health Center Denpasar, Bali, Indonesia. Data were collected during scheduled observation and were analyzed using the Mann-Whitney statistical test.

Intervention: The participants in the treatment group were massaged with frangipani aromatherapy oil by rubbing and pressing the hand palms to the back region at thoracic vertebrae 10,11 , 12 and lumbar 1 levels. The women in the control group were massaged with virgin coconut oil in the same manner as that done to the treatment group.

Main Outcome Measure: This study aimed to investigate the potential of frangipani aromatherapy oil to be used as maternity care in helping pregnant women become more comfortable in the process of normal birthing, based on modified midwife examination form, which contain Numeric Rating Score (NRS), and interviews with the participants to measure the pain intensity.

Result: Before the massage treatment, most of the respondents experienced severe pain. While receiving massage without aromatherapy, respondents mostly still experienced severe pain. However, after a massage treatment using frangipani oil aromatherapy, most respondents experienced reduced pain. There was a statistically significant effect of massage treatment using frangipani aromatherapy oil on the childbirth pain intensity $(p<.001)$.
Conclusion: In this study, massage treatment using frangipani oil aromatherapy decreased the childbirth pain intensity.

KEY WORDS: aromatherapy; frangipani aromatherapy oil; massage therapy; labor pain

\section{INTRODUCTION}

The maternal mortality has been described by World Health Organization (WHO) as the death of women during pregnancy or within 42 days of labor. This death is caused by the pregnancy itself, not caused by accident or injury. (1) Meanwhile, there were 359 cases of maternal mortality in every 100,000 births found in Indonesia, according to the data of Indonesia Demographic and Health Survey 2012.(2) The main factor of maternal mortality caused by the direct obstetric is mostly due to postpartum bleeding $(20.21 \%))^{(3)}$ The longer the duration of childbirth, the weaker the womb contractions become, leading to postpartum bleeding. ${ }^{(4)}$ The duration of childbirth is also linked to the womb muscle contraction, which may lead to the longer childbirth duration if the contraction is not adequate. ${ }^{(5)}$

The previous research explained that the prolongation of childbirth duration is linked to the pain during labor and Apgar score. ${ }^{(6)}$ The long duration of labor leads to complications, such as bleeding and infection, that increase the level of pain and the risk of mortality. ${ }^{(7)}$ The pain during labor is one of the scariest factors faced by pregnant women, so much so that they tend to choose caesarean section delivery to avoid the spontaneous delivery through vagina. ${ }^{(8)}$ Labor pain for many women can be an intense sensation $^{(9,10)}$ that may activate the sympathetic nerve, resulting in increased maternal blood pressure, ${ }^{(11)}$ increased fetal heart rate, ${ }^{(10)}$ uncoordinated uterine contractions, ${ }^{(9)}$ and prolonged labor. ${ }^{(12)}$ Additionally, prolonged labor can lead to maternal and fetus mortality. $(9,10,12,13)$ If the labor pain is not adequately treated, it can cause discomfort and affect the delivery process. ${ }^{(9,10,12)}$ 
Every woman has a different level of pain tolerance that may be influenced by the environment, cultural background, and individual fitness. $(10,13,14,15,16,17)$ Most women think that pain management with medication is the best option, but nonpharmacological methods can be helpful in relieving pain. ${ }^{(18)}$ One solution for reducing childbirth anxiety and labor pain is giving aromatherapy and massage performed by midwives, as it can decrease the level of cesarean section requests. ${ }^{(18,19,20,21,22,23,24,25,26)}$

Frangipani is one of the most common flowers grown in Indonesia, especially in Bali. In general, frangipani is widely used in aesthetical purpose such as production of body scrub, mask, and massage oil. (26) The aroma of frangipani can help people to relax from mentally exhaustion, physical tiredness, and aggressive behavior. ${ }^{(27)}$ As it matters, the women who were given massage with frangipani aromatherapy became calmer in facing the labor, so prolonged labor was prevented. ${ }^{(16)}$ The utilization of the plants' essential oils in physical and emotional improvement has been done as the complementary method in midwifery practice. $(23,28,29)$

However, frangipani aromatherapy is still very rarely used as an alternative therapy to reduce labor pain because it has not been popularized in midwifery practice. Moreover, has been reported to be used as painkiller. ${ }^{(30,31)}$ Therefore, it is necessary to observe the effect of massage using frangipani oil aromatherapy on the childbirth pain intensity in normal childbirth as one step to reduce the morbidity and maternal mortality rates in Indonesia. The purpose of this study is to explore the benefits of massage using frangipani aromatherapy in midwifery practice to reduce labor pain during normal childbirth.

\section{METHODS}

\section{Study Design}

A prospective quasi-experimental research design was used, with pretreatment and posttreatment groups. This type of study is used to explore the influence of independent variables on dependent variables, enabling manipulation of the independent variables. (32) The independent variable was the massage therapy using frangipani aromatherapy oil. Meanwhile, the dependent variable was the childbirth pain intensity during childbirth. The sampling technique was nonprobability consecutive sampling that subjects were chosen according to several criteria.

\section{Participants and Inclusion Criteria}

This study was conducted at Pembantu Dauh Puri Health Center, Denpasar, Bali from June to October 2015. The number of deliveries each month in this health center is between 30 to 40 . This health-care unit also serves the program Social Security Administering Agency (BPJS) and conducts antenatal classes. This unit is one of the leading health service centers in Denpasar City, with a Basic Neonatal Obstetric Service (PONED) facility. Health workers who provided services here consist of two general practitioners, one dentist, 10 midwives divided into three shifts (morning, noon, afternoon), and a dental nurse.

There were 70 pregnant women in labor participating in this study who met the inclusion criteria. The criteria were absence of no complication, the first experience of labor, at maternity the one active phase of cervical opening $(4-5 \mathrm{~cm})$, and signing the informed concern. Pregnant women who will undergo childbirth with cesarean surgery and those unable to communicate clearly (mute or deaf) were excluded from this study. The subjects were divided into treatment and control groups of 35 women in each group. The groups were determined randomly through lottery of number 1 for treatment group and number 0 for control group.

\section{Intervention}

Data were collected after the researchers got the license to conduct the study by Research Ethics Commission of the Faculty of Medicine of Udayana University/General Hospital of Sanglah Denpasar Bali Center No: 1817/UN.14.2/LitBang/2015, followed by the technical explanation and training of midwives in the unit with minimal educational background Diploma III. On average, the midwives are experienced for 5-10 years of practice. The pain intensity was measured before the massage treatment. The treatment group was given frangipani oil aromatherapy and the control group was given virgin coconut oil. The frangipani oil can be used directly to the skin without dilution and without causing irritation. Subjects were massaged by the midwives through rubbing, pressing, and rotating the hand palms on the muscles and soft tissue around thoracic bone $10,11,12$, and lumbar 1 as the pain impulse comes from uterine nerves and cervical nerves. This treatment was given when the subject entered into active phase of cervical opening or about $4 \mathrm{~cm}$ uterine cervix examination through vagina with vagina toucher. Following this, those muscles were massaged continuously for 5-6 hours (every subject got the similar time) during labor process. The massage was terminated after maximum cervical opening was reach. Midwives performed the massage using their two palm and fingers by rubbing the patients gently, firmly, constantly, and slowly forming two small collateral circles. Posttreatment data were collected during labor process. Cervical opening was examined through vaginal examination with vaginal toucher that was followed with numeric rating scale (NRS) according to the Central Hospital Sanglah data collection. 


\section{Outcome Measures}

The childbirth pain intensity was observed using a standard data collection tool (adapted from the Sanglah General Hospital midwife examination form). ${ }^{(33)}$ The form contains the scale of Numeric Rating Scale (NRS) pain. The subjects were asked to rate the pain from 1-10 through numeric rating scale (NRS). Pain was rated 0 if the subject felt no pain, 1-3 for low pain, 4-6 for moderate pain, 7-9 for heavy pain, 10 severe pain (uncontrollable). The measurement of pain intensity was conducted twice, during cervical opening and immediately before the labor. The cervical opening means the childbirth process in phase one, or $4 \mathrm{~cm}$ of cervical opening. The second part was measured when complete opening $(10 \mathrm{~cm})$ of cervix, which indicate the initiation of labor process. The patients were given the data collecting forms on both parts and choose one of the NRS scale based on the pain level. While the patients chose the scale, the authors also examine the patients to validate the given information from patient. This process took 5 minutes for both pretest ( $4 \mathrm{~cm}$ of cervical opening) and posttest (10 $\mathrm{cm}$ of cervical opening).

\section{Statistical Analysis}

The pain intensity data normality was analyzed using Kolmogorov-Smirnov test before bivariable test. As the result, data are not normally distributed with $p$ value $<0.05$. The data were further analyzed by the Mann-Whitney test at $95 \%$ confidence level using SPSS version 19 for Windows (IBM). ${ }^{(32)}$

\section{RESULTS}

The distribution of respondents regarding education level and age between the groups is shown in Table 1. The highest frequency of respondents' education in both groups was Senior High School (SMA) (68.57\% in control and $80 \%$ in treatment group). The age distribution of the respondents in both groups ranged from 20-29 years $(62.86 \%$ for both groups); no respondent was below 20 years or above 40 years. More than half of the respondents in both groups had an occupation. Most respondents were Balinese $(62.86 \%$ and $54.29 \%$ in control and treatment group, respectively).

Table 2 shows that most of the pain intensity of the respondents in both pretreatment groups (treatment and control) before massage therapy was almost the same on the pain scale of 7-9 (severe pain), which account $94.29 \%$ and $97.4 \%$ respondents in control and treatment group, respectively. The respondents in treatment group were mostly $(54.29 \%$ of all respondent) experienced lower pain intensity on the pain scale 4-6 (middle pain) than the control group after treatment. Meanwhile, in control group the pain
TABLE 1. Subjects' Characteristics

\begin{tabular}{|c|c|c|c|c|}
\hline \multirow{2}{*}{ Characteristics } & \multicolumn{2}{|c|}{ Control Group } & \multicolumn{2}{|c|}{ Treatment Group } \\
\hline & $n$ & $\%$ & $n$ & $\%$ \\
\hline \multicolumn{5}{|l|}{ 1. Education } \\
\hline Elementary School & 1 & 2.86 & 0 & 0 \\
\hline Junior High School & 10 & 28.57 & 3 & 8.57 \\
\hline Senior High School & 24 & 68.57 & 28 & 80 \\
\hline College & 0 & 0 & 4 & 11.43 \\
\hline Total & 35 & 100 & 35 & 100 \\
\hline \multicolumn{5}{|l|}{ 2. Age } \\
\hline$<20$ years old & 0 & 0 & 0 & 0 \\
\hline 20-29 years old & 22 & 62.86 & 22 & 62.86 \\
\hline 30-39 years old & 13 & 37.14 & 13 & 37.14 \\
\hline$\geq 40$ years old & 0 & 0 & 0 & 0 \\
\hline Age & 35 & 100 & 35 & 100 \\
\hline \multicolumn{5}{|l|}{ 3. Occupation } \\
\hline Merchant & 8 & 22.86 & 5 & 14.29 \\
\hline laborer & 3 & 8.57 & 4 & 11.43 \\
\hline Civil servant & 2 & 5.71 & 1 & 2.86 \\
\hline Private & 21 & 60.00 & 23 & 65.71 \\
\hline Housewife & 1 & 2.86 & 2 & 5.71 \\
\hline Total & 35 & 100 & 35 & 100 \\
\hline \multicolumn{5}{|l|}{ 4. Race } \\
\hline Balinese & 22 & 62.86 & 19 & 54.29 \\
\hline Javanese & 12 & 34.28 & 15 & 42.85 \\
\hline Flores/Ende & 1 & 2.86 & 1 & 2.86 \\
\hline Total & 35 & 100 & 35 & 100 \\
\hline
\end{tabular}

TABLE 2. Pain Intensity Comparison with Before and After the Massage Treatment

\begin{tabular}{|c|c|c|c|c|c|c|c|c|c|c|}
\hline \multirow{3}{*}{$\begin{array}{l}\text { Pain } \\
\text { Scale }\end{array}$} & \multicolumn{4}{|c|}{ Before Treatment } & \multicolumn{5}{|c|}{ After Treatment } & \multirow{3}{*}{ Sig. } \\
\hline & \multicolumn{2}{|c|}{$\begin{array}{c}\text { Control } \\
\text { Group }\end{array}$} & \multicolumn{2}{|c|}{$\begin{array}{l}\text { Treatment } \\
\text { Group }\end{array}$} & \multirow[t]{2}{*}{ Sig. } & \multicolumn{2}{|c|}{$\begin{array}{l}\text { Control } \\
\text { Group }\end{array}$} & \multicolumn{2}{|c|}{$\begin{array}{l}\text { Treatment } \\
\text { Group }\end{array}$} & \\
\hline & $n$ & $\%$ & $n$ & $\%$ & & $n$ & $\%$ & $n$ & $\%$ & \\
\hline $0-3$ & 0 & 0 & 0 & 0 & & 0 & 0 & 0 & 0 & \\
\hline & & & & & $p>.05$ & & & & & $p<.01$ \\
\hline $4-6$ & 2 & 5.71 & 1 & 2.86 & & 5 & 14.29 & 19 & 54.29 & \\
\hline $7-9$ & 33 & 94.29 & 34 & 97.14 & & 30 & 85.71 & 16 & 45.71 & \\
\hline Total & 35 & 100 & 35 & 100 & & 35 & 100 & 35 & 100 & \\
\hline
\end{tabular}

intensity changed, but not as much as in the treatment group; $85.71 \%$ still experienced severe pain. Statistical analysis of pain intensity in the pre (control and treatment) group obtained no significant differences $(p>.05)$, and there were significant differences ( $p$ $<.01)$ in the postgroup, both control and treatment.

Table 3 reveals that the childbirth pain intensity was found lower in the treatment group (median 6) 
TABLE 3. The Differences of Childbirth Pain Intensity with Massage Using Frangipani Aromatherapy Oil and Nonaromatherapy Oil

\begin{tabular}{|c|c|c|c|}
\hline Variable & $n$ & $\begin{array}{l}\text { Median } \\
\text { (minimum- } \\
\text { maximum) }\end{array}$ & $\begin{array}{c}Z \\
\text { value }\end{array}$ \\
\hline $\begin{array}{l}\text { Childbirth pain intensity with } \\
\text { massage using non-aromatherapy }\end{array}$ & 35 & $7(6-9)$ & $3.62<.001$ \\
\hline $\begin{array}{l}\text { Childbirth pain intensity with } \\
\text { massage using Frangipani } \\
\text { aromatherapy oil }\end{array}$ & 35 & $6(6-9)$ & \\
\hline
\end{tabular}

than in the control group (median 7), with $\mathrm{Z}$ score of $-3.62(p<.001)$.

\section{DISCUSSION}

The childbirth pain intensity of respondents who were massaged using aromatherapy oil was lower than that in the respondents who were massaged with nonaromatherapy oil $(p<.01)$. The childbirth pain intensity before massage therapy using frangipani aromatherapy oil in both groups (treated and control) was mostly on the scale 7-9 (severe pain). After therapy, the labor pain intensity in the control group remained the same. However, the labor pain was reduced to 4-6 (moderate pain) in the treatment group.

Frangipani contains active compounds such as triterpenoid and amyrin that can act as a relaxant and reduce pain. ${ }^{(34)}$ Frangipani smells good and fresh, its aroma is received by nose receptors that transfers the signal to brain in the emotional and memory control area, signaling the hypothalamus as the control of stress. ${ }^{(35,36,37)}$ The fragrance of frangipani is produced from the essential compounds, namely geraniol, citronellol, and linalool. ${ }^{(38,39,40)}$ The smeared frangipani oil in the skin will bind to the steroid group of sweat glands called osmon. ${ }^{41,42)}$ This steroid group stimulated the thalamus to produce enkephalin as the natural pain killer and give safe sensation. ${ }^{(29)}$ When a woman feels relaxed, the endorphin hormone will be produced as the natural sedative so the pain sensation decreases. ${ }^{(22)}$

Massage was performed by applying hand pressure on soft tissue, usually muscles or ligaments, causing movement or position changes to relieve pain, produce relaxation and enhance circulation. $(10,18,19,21,26,27,28)$ Massage and aromatherapy using frangipani provide benefits physiologically and psychologically. $(26,27,28)$ Physiologically, pain impulses can be regulated or inhibited by central nervous system defense mechanisms in accordance with the gain control theory. $(10,29,32)$ Psychologically, frangipani aromatherapy can promote comfort and relaxation because it can ease tension and anxiety. $(10,26,27)$

Most of the respondents were high school graduates $(68.57 \%$ and $80 \%$ in control and treatment group, respectively); most of the remaining respondents had been educated to above basic levels, graduated from junior high school $(28.57 \%$ and $8.57 \%$ in control and treatment group) or college $(11.43 \%$ in treatment group only). This allowed respondents to receive and understand information about pain management. The level of education may affect maternal psychosocial related to the preparation and expectation of childbirth. $(14,15,43,44,45,46)$ Education also affects maternal knowledge about childbirth, including labor pain and pain management. ${ }^{(9,16,17)}$ The results showed that most respondents who have moderate levels of education will have a better understanding of the labor process, and will be prepared better for labor pain than the respondent with lower education level. $(14,15,16,17,46)$

Most of the respondents were aged between 20 and 29 years (62.89\% of both groups). There was no respondent below 20 years or above 39 years (Table 1). Age is one of the factors affecting the experience of labor pain. The results of this study are supported by research conducted by Vigil et al. ${ }^{(16)}$ in 2014 which stated age is one of the factors affecting labor pain. Teenage pregnancy can be psychologically stressing and may increase the perception of pain as the result of anxiety and stress. $(9,15,16,17)$

Before massage therapy, the pain intensity of both groups was mostly 7-9 (severe pain), as reported by 94\% (control group) and 97\% (treatment group) of respondents. Statistical analysis observed no significant difference $(p>.05)$ in the premassage therapy for both control and treatment group. Significant difference $(p<0.01)$ in the response was observed after the massage therapy, with the decrease of severe pain in respondents in the treatment group (Table 2). Respondents showed a moderate degree of objectively manifested histone; for example, hissing and grinning, they were able to pinpoint the location of pain correctly and were able to describe, followed orders well, and were responsive to manual actions during the observation in phase 1 and immediately before labor. Severe pain manifestations indicated by respondents objectively may not follow medical instructor orders but are still responsive to actions, may indicate the location of pain, cannot describe it, cannot be set for the position, breath length changes. ${ }^{(10,14,28,32)}$ The results of the research conducted by Ali et al. ${ }^{(38)}$ in Maternity Hospital (RB) Kasih Ibu Jatirogo Tuban, East Java were in line with the results of this study, that most laboring mothers experienced moderate and severe pain as assessed by a numeric rating scale (NRS). Research in Brazil also found that most mothers experienced moderate and severe pain during labor. ${ }^{(47)}$

Table 2 shows that the massage therapy using frangipani aromatherapy oil is demonstrated to have an effect on the labor pain. Most respondents who were treated with the massage using frangipani aromatherapy experienced moderate pain intensity $(54.29 \%)$, while most of the respondents in the control 
group had severe pain (85.71\%). Dhany et al., ${ }^{(26)}$ who had conducted their research in southwest England, suggested that the pregnant women who were massaged for 20 minutes every hour during labor had significantly reduced level of labor pain. This may be due to the fact that massage stimulates the body to release endorphin as natural pain killers. ${ }^{(18,26,27,36,47,48)}$

In addition, according to Makvandi et al., (36) lavender aromatherapy that was given to women after caesarean section had shown a positive effect in decreasing the pain intensity. Likewise, study by Vaziri et al. (25) shows that the lavender aromatherapy helped to decrease the pain after childbirth. Labor pain arises as a result of uterine contractions that cause dilation of the uterine cervix and effacement (cervical thinning), decreased fetal head, and uterine ischemia (decreased blood flow causing tissue oxygen deficiency). ${ }^{(7,10,28)}$ The results support the theory that emphasis and scrubbing can prevent or inhibit pain impulses derived from the cervix and corpus uteri. ${ }^{(9,10,19,26,27,28,35)}$ The results of this study demonstrate that massage with frangipani oil was associated with lower pain intensity. Moreover, rose essential oil has also reduced the pain after labor. ${ }^{(49)}$ Massaging with frangipani oil will cause the oil to be absorbed by body via hair follicle and sweat gland. ${ }^{(48)}$ The oil contain analgesic property by inhibiting cyclooxygenases and or lipoxygenase, which may contribute the decrease in pain index from severe $(97.14 \%)$ to moderate $(45.71 \%)$. $^{(50)}$ Moreover, aromatherapy also stimulates the thalamus to remove enkephalin that serves as a natural painkiller. ${ }^{(26,27,34,36,42,46,50)}$

On the other hand, massage therapy can activate large diameter nerve fibers to shrink as the paincovering mechanism of the cerebral cortex leading to pain reduction. ${ }^{(9,18,19,21,26,28,36,50)}$ The combination of massage with aromatherapy frangipani oil was expected to reduce labor pain significantly. Furthermore, the greater number of subjects may help to improve the collected data, as it will need the control group without massage treatment. ${ }^{(42)}$

Midwives were advised to implement massage using frangipani aromatherapy oil when providing maternity care to help pregnant women become more comfortable to have normal delivery. Health agencies which provide services to pregnant women can make Standard Operating Procedures (SOP) pain management with massage techniques using aromatherapy frangipani oil. For future researchers to further examine, it is necessary to compare aromatherapy frangipani with other aromatherapy in order to improve the midwifery care based on local wisdom. However, there was no unmassaged control group in this study, as the number of labor women is limited. Besides, the time limit also contributes in the drawbacks of this study due to the deadline from the funding body, which is Daftar Isian Proyek Anggaran (DIPA).

\section{CONCLUSION}

Based on the results, the utilization of frangipani aromatherapy oil decreases the pain intensity level during labor. This implies that the pain intensity during labor can be decreased through simple strategies by using the local natural resources. Massaging with frangipani (Plumeria) oil, which is commonly found in tropical areas such as Bali, Indonesia, can help women in labor feel more comfortable and less stress during the labor process. Therefore, it can be suggested that this method can be an alternative nonpharmacological way to decrease the pain suffered by women during labor.

\section{ACKNOWLEDGMENTS}

The authors would like to thank the Ministry of Finance for funding this research through the DIPA program. This study was approved by the Ethics Committee of Fakultas Kedokteran Universitas Udayana/ Rumah Sakit Umum Pusat Sanglah Denpasar, Bali, and funded by Daftar Isian Proyek Anggaran (DIPA) from the Indonesian Health Ministry.

\section{CONFLICT OF INTEREST NOTIFICATION}

The authors declare there are no conflicts of interest.

\section{COPYRIGHT}

Published under the CreativeCommons AttributionNonCommercial-NoDerivs 3.0 License.

\section{REFERENCES}

1. Say L, Chou D, Gemmill A, Tuncalp O, Moller A-B, Daniels $\mathrm{J}$, et al. Global causes of maternal death: a WHO systematic analysis. Lancet Glob Health. 2014;2(6):e323-333.

2. Mahmood MA, Mufidah I, Scroggs S, Siddiqui AR, Raheel $\mathrm{H}$, Wibdarminto K, et al. Root-cause analysis of persistently high maternal mortality in a rural district of Indonesia: role of clinical care quality and health services organizational factors. BioMed Res Int. 2018;3673265:1-11.

3. Tort J, Rozenberg P, Traore M, Fournier P, Dumont A. Factors associated with postpartum hemorrhage maternal death in referral hospitals in Senegal and Mali: a cross-sectional epidemiological survey. BMC Pregnancy Childbirth. 2015;15(1):235.

4. Beghiti J, Kayem G, Dupont C, Rudigoz R-C, Bouvier-Colle $\mathrm{M}-\mathrm{H}$, Deneux-Tharaux C. Oxytocin during labour and risk of severe postpartum haemorrhage: a population-based, cohortnested case-control study. BMC Open. 2011;1(2):e000514.

5. Asthon-Miller JA, DeLancey JOL. On the biomechanics of vaginal birth and common sequelae. Ann Rev Biomed Eng. 2009:11:163-176. 
6. Altman M, Sandstrom A, Patterson G, Frisell T, Cnattingius $\mathrm{S}$, Stephansson O. Prolonged second stage of labor is associated with low Apgar score. Eur J Epidemiol. 2015;30(11): 1209-1215.

7. Merdad L, Ali MM. Timing of maternal death: levels, trends, and ecological correlates using sibling data from 34 subSaharan Africa countries. PLoS ONE. 2018;13(1):e0189416.

8. Gholami A, Salarilak S. Why do some pregnant women prefer Cesarean delivery in first pregnancy? Iran J Reprod Med. 2013;11(4):301-308.

9. Khanahmadi S. Outcomes assessment of pain techniques use in labour in order to increase painless normal delivery rate. Int J Women's Health Reprod Sci. 2013;1(1):1-4.

10. Beigi NMA, Broumandfar K, Bahadoran P, Abedi HA. Women's experience of pain during childbirth. Iran J Nurs Midwifery Res. 2010;15(2):77-82.

11. Hidaka R, Callister LC. Giving birth with epidural analgesia: the experience of first-time mothers. J Perinat Educ. 2012;21(1):24-35.

12. Mashaqbeh M, AbuRuz ME. Pain management: a systematic review. J Nurs Health Sci. 2017;6(1):75-80.

13. Kheirkhah M, Valipour NS, Neisani L, Haghani H. A controlled trial of the effect of aromatherapy on birth outcomes using "rose essential oil" inhalation and foot bath. J Midwifery Reprod Health. 2014;2(1):77-82.

14. Aziato L, Acheampong AK, Umoar KL. Labour pain experiences and perceptions: a qualitative study among post-partum women in Ghana. BMC Prenancy Childbirth. 2017;17(1):73.

15. Wandner LD, Scipio CD, Hirsh AT, Torres CA, Robinson ME. The perception of pain in others: how gender, race, and age influence pain expectations. J Pain. 2012;13(3):220-227.

16. Vigil JM, Torres D, Wolff A, Hughes K. Exposure to virtual social stimuli modulates subjective pain reports. Pain Res Manag. 2014;19(4):e103-e108.

17. Afolayan JA, Oyeleye DI, Adebiyi FO, Durojaiye AO, Bitrus D. Factors influencing perception of pain among clients attending a Nigeria teaching hospital. Int J Nurs Midwifery. 2015:7(8):133-140.

18. Hosseni SF, Pilevarzadeh, Vazirinasab. Non-pharmacological strategies on pain relief during labor. Biosci Biostech Res Asia. 2016;13(2):701-706.

19. Lamadah SM, Nomani I. The effect of aromatherapy massage using lavender oil on the level of pain and anxiety during labour among primigravida women. Am J Nurs Sci. 2016;5(2):37-44.

20. Field T. Pregnancy and labour massage. Expert Rev Obstet Gynecol. 2010;5(2):177-181.

21. Alleemudder DI, Kuponiyi Y, Kuponiyi C, McGlennan A, Fountain S, Kasivisvanathan R. Analgesia for labour: an evidence-based insight for the obstetrician. Obstet Gynecol. 2015;17(3):147-155.

22. Fawaz MA, El-Sharkawy NB. Effect of LI4 (Hoku point) massage with ice on labor duration during the active phase of labor among women delivering at El Manial University Maternity Hospital. Egypt Nurs J. 2016;13(3):178-185.

23. Betran AP, Ye J, Moller AB, Zhang J, Gulmezoglu AM, Torloni MR. The increasing trend in caesarean section rates: global, regional and national estimates: 1990-2014. PLOS ONE. 2016;11(2):e0148343.
24. Steel A, Adams J, Sibbritt D, Broom A, Gallois C, Frawley J. Managing the pain of labour: factors associated with the use of labour pain management for pregnant Australian Women. Health Expect. 2015;18(5):1633-1644.

25. Vaziri F, Shiravani M, Najib FS, Pourahmad S, Salehi A, Yazdanpanahi Z. Effect of lavender oil aroma in the early hours of postpartum period on maternal pains, fatigue, and mood: a randomized clinical trial. Int J Prev Med. 2017;8:29.

26. Dhany A, Mitchell T, Foy C. Aromatherapy and massage intrapartum service impact on use of analgesia and anethesia in women in labour: a retrospective case note analysis. J Altern Complement Med. 2012;18(10):932-938.

27. Dubey S, Lata S. Self-comforting techniques and non-pharmacological methods to relieve pain during labor. Int J Sci Res. 2015;6(1):1594-1599.

28. Can HO, Saruhan A. Evaluation of the effects of ice massage applied to large intestine 4 (hegu) on postpartum pain during the active phase of labor. Iran J Nurs Midwifery Res. 2015;20(1):129-138.

29. Kolacz J, Porges SW. Chronic diffuse pain and functional gastrointestinal disorders after traumatic stress: pathophysiology through a polyvagal perspective. Front Med (Lausanne). 2018;5.

30. Verma S. Multipurpose ornamental plant Plumeria rubra Linn (Apocynaceae). IJSRSET. 2016;2(4):646-649.

31. Zaheer Z, Konale AG, Patel KA, Khan S, Ahmed RZ. Comparataive phytochemical screening of flowers of Plumeria alba and Plumeria rubra. Asian J Pharm Clin Res. 2010;3(4):1-2.

32. Zouikr I, Bartholomeusz MD, Hodgson DM. Early life programming of pain: focus on neuroimmune to endocrine communication. J Transl Med. 2016;14(1):123.

33. RSUP Sanglah Denpasar. Pengkajian Medis dan Kebidanan Gawat Darurat Obstetrik. RM.10.4/ER/2015. Bali, Indosnesia: Sanglah General Hospital [manual procedure].

34. Ali B, Al-Wabel NA, Shams S, Ahamad A, Khan SA, Anwar F. Essential oils used in aromatherapy: a systemic review. Asian PaK J Trop Biomed. 2015;5(8):601-611.

35. Sangwin MKJ. A study on stress and aromatherapy intervention efficacy [Undergraduate Theses and Professional Papers]. Missoula, MT: University of Montana. Available from: https://scholarworks.umt.edu/cgi/viewcontent. cgi?article $=1079 \&$ context $=$ utpp. Updated May, 2016. Accessed April 9, 2017.

36. Makvandi S, Mirteimoori M, Mirzaiinajmadi KM, Sadeghi R. A review of randomized clinical trials on the effect of aromatherapy with lavender on labor pain relief. Nurse Care Open Acces J. 2016;1(3):1-6.

37. Jost X, Ansel J-L, Lecellier G, Raharivelomanana P, Butaud J-F. Ethnobotanical survey of cosmetic plants used in Marquesas Islands (French Polynesia). J Ethnobiol Ethnomed. 2016;12(1):55.

38. Ali N, Ahmad D, Bakht J. Antimicrobial activity of different solvent extracted samples from the flowers of medicinally important Plumeria obstusa. Pak J Pharm Sci. 2015;28(1): 195-200.

39. Martinez-Garcia R, Garcia-Martinez T, Puig-Pujol A, Mauricio JC, Moreno J. Changes in sparkling wine aroma during the second fermentation under $\mathrm{CO} 2$ pressure in sealed bottle. Food Chem. 2017;237:1030-1040. 
40. Srivastava G, Gupta A, Singh MP, Mishra A. Pharmacognostic standardization and chromatographic fingerprint analysis on triterpenoids constituents of the medicinally important plant Plumeria rubra f. rubra by HPTLC technique. Pharmacogenomics J. 2017;9(2):135-141.

41. Miller T. Dermal absorption of essential oils. Naturopathic Doctor News \& Reviews [website]. Available from: https://ndnr. com/mindbody/dermal-absorption-of-essential-oils/. Updated June 2, 2015. Accessed April 9, 2017.

42. Herman A, Herman AP. Essential oils and their constituents as skin penetration enchancer for transdermal drug delivery: a review. J Pharm Pharmacol. 2015;67(4):473-85.

43. Husni MA, Murniana, Helwati H, Nuraini. Antimicrobial activity of n-hexane extracts of red frangipani (Plumeria rocea). Jurnal Natural. 2013;13(1):28-33.

44. Duncan LG, Cohn MA, Chao MT, Cook JG, Riccobono J, Bardacke N. Benefits of preparing for childbirth with mindfulness training: a randomized controlled trial with active comparison. BMC Pregnancy Childbirth. 2017;17(1):140.

45. Lally JE, Thomson RG, MacPhail S, Exley C. Pain relief in labour: a qualitative study to determine how to support women to make decisions about pain relief in labour. BMC Pregnancy Childbirth. 2014;14(1):6.
46. Cho MY, Min ES, Hur MH, Lee MS. Effects of aromatherapy on the anxiety, vital signs, and sleep quality of percutaneous coronary intervention patients in intensive care units. EvidBased Complement Alt Med. 2013;2013.

47. Silva Gallo RB, Santana LS, Ferrira CH, Marcolin AC, Polineto $\mathrm{OB}$, Duarte G, et al. Massage reduced severity of pain during labour: a randomised trial. J Physiother. 2013;59(2):109-116.

48. Dixon L, Skiner JP, Foureur M. The emotional and hormonal pathways of labour and birth: integrating mind, body, and behaviour. J New Zealand Coll Midwives. 2013;48(1):15-23.

49. Kheirkhah M, Setayesh Valipor N, Neisani L, Haghani H. A controlled trial of the effect aromatherapy on birth outcomes using "rose essential oil" inhalation and foot bath. J Midwifery Reprod Health. 2014;2(1):77-82.

50. Bolbol-Haghighi N, Masoumi SZ, Kazemi F. Effect of massage therapy on duration of labour: a randomized controlled trial. $J$ Clin Diagn Res. 2016;10(4):QC12-QC15.

Corresponding author: Ni Gusti Kompiang Sriasih, Department of Midwifery, Polytechnic of Denpasar, Denpasar, Bali, Indonesia

E-mail: sriasihkespro@gmail.com 